\title{
FEEDING PREFERENCES OF THE INVASIVE CRAYFISH, PROCAMBARUS CLARKII
}

\author{
Francesca Gherardi* and Silvia Barbaresi
}

\author{
Dipartimento di Biologia Animale e Genetica, Università di Firenze, \\ Via Romana 17, 50125 Firenze, Italy \\ E-Mail: francesca.gherardi@unifi.it \\ * To whom correspondence should be addressed.
}

Reçu le 5 octobre 2007

Received October 5, 2007

Accepted le 12 décembre 2007

Accepted December 12, 2007

\begin{abstract}
This laboratory study analyzes feeding preferences of a crayfish species with high invasive potentials, the red swamp crayfish Procambarus clarkii. We first conducted a series of multiple-choice tests among fresh plants ( 3 tests, one per each of three seasons, i.e. spring, summer, and autumn) and animals (1 test in summer). In the first tests, crayfish were simultaneously offered fresh pieces of seven plants of different growth forms and taxonomic groups, selected on the basis of their availability in the habitat. In the second test, the offered animals were dead earthworms, rainbow trout fry, and toad tadpoles. Then, a binary choice test was run in autumn between the most preferred plant (Urtica sp.) and earthworms. The percentages of organic $\mathrm{C}$ and $\mathrm{N}$ contents were measured for each food category using a gas-chromatography technique and the assimilation efficiency of both dry mass and organic content was assessed in a dedicated experiment. The results showed that $P$. clarkii is selective when offered fresh plants, consuming a relatively larger biomass of Urtica (in the three seasons examined), green algae (in spring), and Polygonum (in summer and autumn). Surprisingly, crayfish did not exhibit preference for any animal prey. Also, $P$. clarkii's feeding decisions seemed not to be associated with either the availability of plants in the habitat or their occurrence in the gut contents of wild crayfish. Neither did their ingested biomass depend on the organic content or assimilation efficiency. Procambarus clarkii preferred Urtica sp. over earthworms, notwithstanding the higher nutritional value and assimilation efficiency of the latter. The above results might suggest that feeding preferences of the species often depend on factors other than nutritional value and digestibility. Future studies will analyze all the possible factors together in order to unravel the rules that govern feeding preferences in crayfish. In the case of invasive species, such knowledge will highly contribute to planning science-based actions for their containment and mitigation.
\end{abstract}

Key-words: feeding preferences, assimilation efficiency, invasive species, crayfish, Procambarus clarkii.

\section{PRÉFÉRENCES ALIMENTAIRES DE L'ÉCREVISSE INVASIVE PROCAMBARUS CLARKII}

\section{RÉSUMÉ}

Lors de cette étude de laboratoire nous avons analysé les préférences alimentaires d'une espèce d'écrevisse ayant un fort potentiel invasif, l'écrevisse rouge des marais 
Procambarus clarkii. Nous avons d'abord conduit une série de tests à choix multiples avec trois plantes fraîches (3 tests, un pour les trois saisons, i.e.; printemps, été, automne) et avec des animaux (1 test). Dans les premiers tests, des morceaux frais de sept plantes de formes de croissance différentes et de groupes taxonomiques différents, choisies pour leur disponibilité dans l'habitat, ont été proposés aux écrevisses. Dans le second test, les animaux proposés étaient des vers de terre morts, des alevins de truite arc-en-ciel, et des têtards de crapaud. Ensuite un test à choix binaire a été conduit entre la plante favorite (Urtica sp.) et des vers de terre. Le pourcentage en teneur organique ( $\mathrm{C}$ et $\mathrm{N})$ a été mesuré pour chaque catégorie d'aliment en utilisant la technique par chromatographie gazeuse et l'efficacité de l'assimilation à la fois de la masse sèche et du contenu organique a été établie à l'aide d'une expérimentation spécifique. Les résultats indiquent que P. clarkii est sélective lorsqu'on lui propose des plantes fraîches, consommant une quantité relativement plus importante d'Urtica (lors des trois saisons examinées), d'algues vertes (au printemps), et de Polygonum (en été et en automne). De façon surprenante, les écrevisses n'ont manifesté de préférence pour aucune des proies animales proposées. De plus, les décisions alimentaires de P. clarkii ont semblé n'avoir aucun rapport avec la disponibilité d'aucune des plantes dans l'habitat ou leur présence dans le contenu stomacal des écrevisses sauvages. Pas plus que la biomasse ingérée n'avait de rapport avec la teneur organique ou l'efficacité de l'assimilation. Procambarus clarkii préfère Urtica $s p$. au vers de terre, en dépit de la valeur nutritionnelle plus élevée de ce dernier, et de sa plus grande efficacité d'assimilation. Les résultats ci-dessous pourraient suggérer que les préférences alimentaires de l'espèce dépendent souvent de facteurs autres que la valeur nutritionnelle et la digestibilité. De prochaines études analyseront tous les facteurs possibles ensemble afin de découvrir les règles qui gouvernent les préférences alimentaires des écrevisses. Dans le cas des espèces invasives, de telles connaissances contribueront grandement à la planification d'actions scientifiquement fondées, en vue du contrôle et de la réduction de leur expansion.

Mots-clés: préférences alimentaires, assimilation, efficacité, espèces invasives, écrevisses, Procambarus clarkii.

\section{INTRODUCTION}

Crayfish are important polytrophic consumers in lotic and lentic systems (MOMOT, 1995). Due to their extensive feeding on benthic invertebrates, detritus, macrophytes, and algae (e.g. WHITLEDGE and RABENI, 1997), they play complex roles in the aquatic community (CORREIA, 2003), often acting as keystone species (NYSTRÖM, 2002). Because of their capability to integrate into the food web at many levels, once added to a system their ecological impact can be large (NYSTRÖM, 1999; GHERARDI, 2007). In the short term, the introduced crayfish have the potential to impose "considerable environmental stress" to the recipient ecosystem (HOBBS et al., 1989), decreasing, even at relatively low densities, the biomass and species richness of macroinvertebrates, macrophytes, and periphyton (e.g. LODGE and LORMAN, 1987). In the long term, they may induce "irreparable shifts in species diversity" (HOBBS et al., 1989), thus contributing to the decline of invertebrate taxa, amphibians, and fish (e.g. GUAN and WILES, 1997).

Several microcosm and mesocosm studies have shown the ability of introduced crayfish to reduce the standing stock of aquatic plants and the density of benthic invertebrates (e.g. LODGE et al., 1994; NYSTRÖM et al., 2001; GHERARDI and ACQUISTAPACE, 2007). Laboratory experiments have described their predatory efficiency when offered mollusks, amphibians, and fish (GHERARDI et al., 2001; RENAI and GHERARDI, 2004), and field studies have revealed their ability to prey upon both newt eggs (GAMRADT and KATS, 1996) and the embryos and free swimming larvae of up to 13 amphibian species (CRUZ and REBELO, 2005). 
Surprisingly, little is known about feeding preferences of introduced crayfish species (FEMINELLA and RESH, 1989; ILHÉU and BERNARDO, 1993, 1995; CRONIN et al., 2002), notwithstanding that, by feeding selectively, they may exert a strong negative impact on the most consumed resources, thus contributing to biodiversity loss and promoting the homogenization of the invaded community (WARNER and GREEN, 1995; NYSTRÖM et al., 1996).

The purpose of this laboratory study was to analyze feeding preferences of a crayfish species with high invasive potentials, the red swamp crayfish Procambarus clarkii (GHERARDI, 2006).

\section{METHODS}

\section{Crayfish capture and maintenance}

A total of 200 adult crayfish of both sexes (cephalothorax length: 44.7-64.4 mm) was collected between April 1998 and June 1999 in Osmannoro (Florence, Italy) from a ditch system composed of a net of about $1.5-\mathrm{m}$ wide canals with $15-25 \mathrm{~cm}$ water depth (GHERARDI et al., 2000; BARBARESI et al., 2004). In the laboratory, crayfish were maintained in individual aquaria $(45 \times 15 \mathrm{~cm})$ in a temperature controlled $\left(19 \pm 0.9^{\circ} \mathrm{C}\right)$ room at a natural light:dark cycle regime. They were starved for 10 days prior to the experiments.

\section{Choice experiments}

We first conducted two series of multiple choice tests, three among fresh plants (20 replicates each) and one among animals (20 replicates). Vegetal detritus was not tested in the present study because analyzed in a previous experiment by ILHÉU and BERNARDO (1995). We did not distinguish between males and females since a companion study in the same area had not revealed any sexual difference in the diet of this species (GHERARDI and BARBARESI, 2008). Tests among plants were done during three sessions in spring, summer, and autumn 1998. Fresh pieces of seven plants were simultaneously presented to the crayfish. Experimental plants (see Table I for specific names and abbreviations) belonged to a wide array of growth forms and taxonomic groups. They were selected on the basis of their availability in the habitat during each season, as assessed by measuring, by the use of a $50-\mathrm{m}^{2}$ grid, the percent area covered by each plant in four $200-\mathrm{m}$ transects (two in the water and two on the banks) traced along a 1.5-m width irrigation ditch (20 replicates per transect) (see Table I for their percent coverage). Plants were all used in the experiments within $24 \mathrm{~h}$ from their collection.

Crayfish preference among animals was tested in summer 1998 using earthworms (Lumbricus terrestris) (Ea, 2 specimens), rainbow trout (Oncorhynchus mykiss) fry (Fi, 1 specimen), and toad (Bufo bufo) tadpoles (Ta, 5 specimens). To eliminate their mobility and thus the influence of differential rates of encounters, the animals were killed immediately before the experiment in a freezer at $-30{ }^{\circ} \mathrm{C}$, where death occurred after a few seconds without any apparent sufferance by the animal. Pilot tests showed that defrosted prey were still attractive to crayfish. A third choice test was conducted in autumn 1998 (20 replicates) when crayfish were offered both the plant they showed to prefer in the previous experiments (Ur) and Ea.

In each replicate, crayfish were allowed to food ad libitum on wet pre-weighted mass of a similar volume of the different food categories. Different foods were placed near to the border of a circular experimental aquarium (diameter: $50 \mathrm{~cm}$ ), equally spaced from each other following a randomized order per replicate, and anchored to the bottom using a metal weight. This arrangement limited experimental bias and contemporaneously assured that the crayfish, once put onto the centre of the aquarium, had the same chance of encountering each food category. No crayfish was used more than once. 


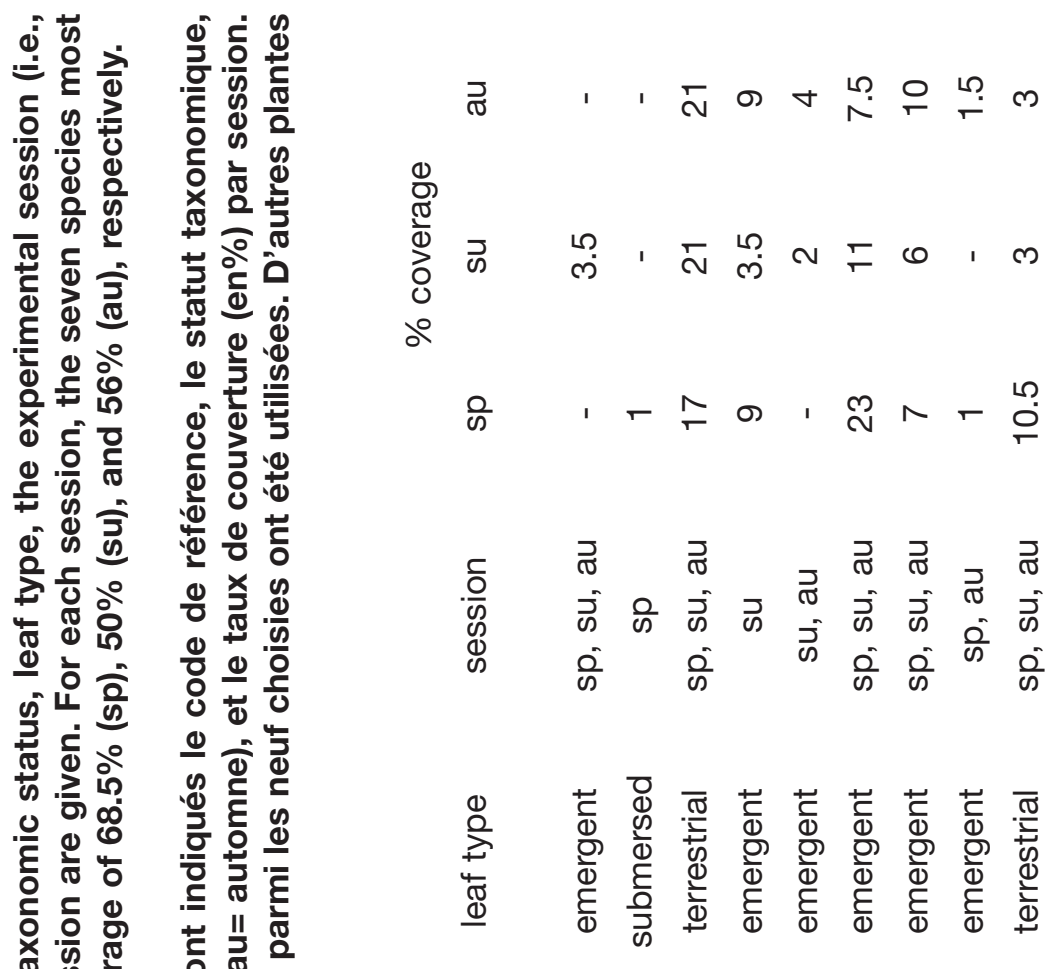

సٓ

ठั

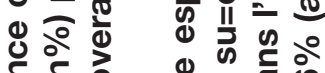

बํ.

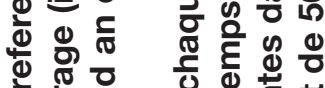

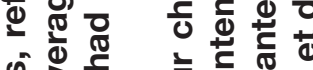

क⿺辶寸

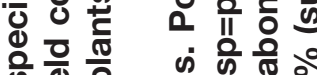

क舟 흔

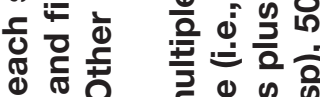

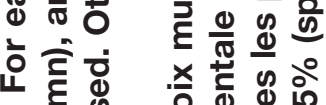

एं

范予

\& II

응 त

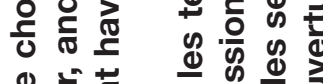

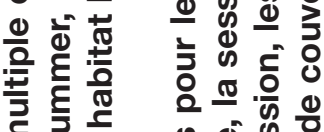

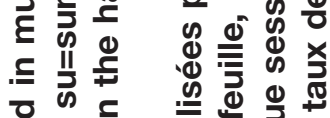

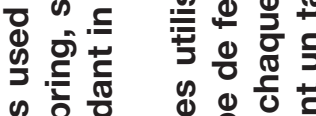

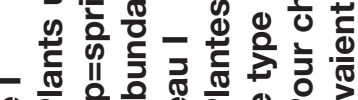
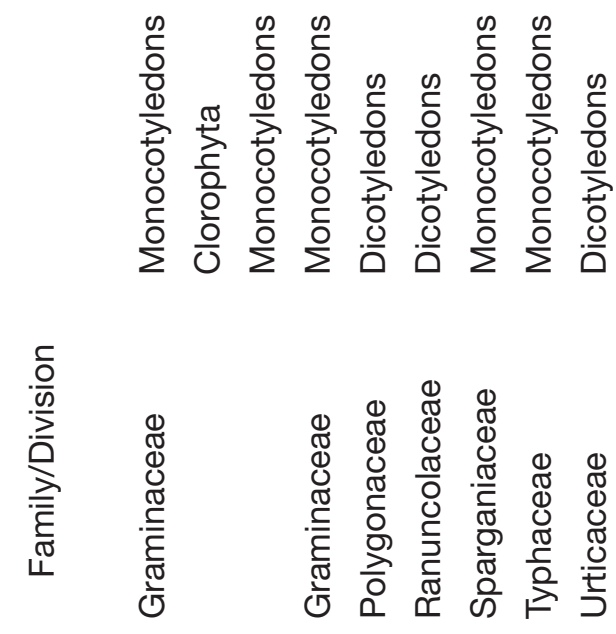

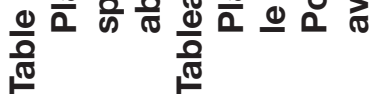

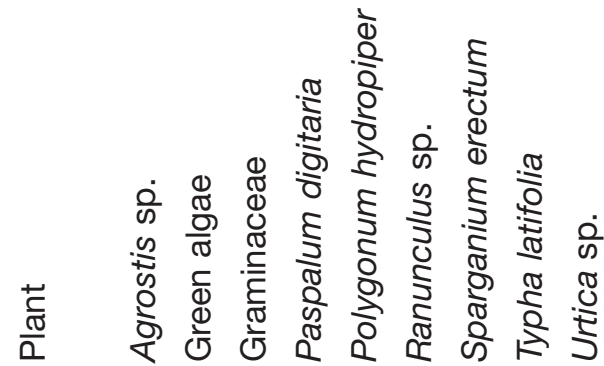

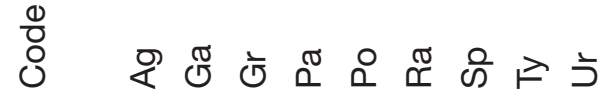


spring

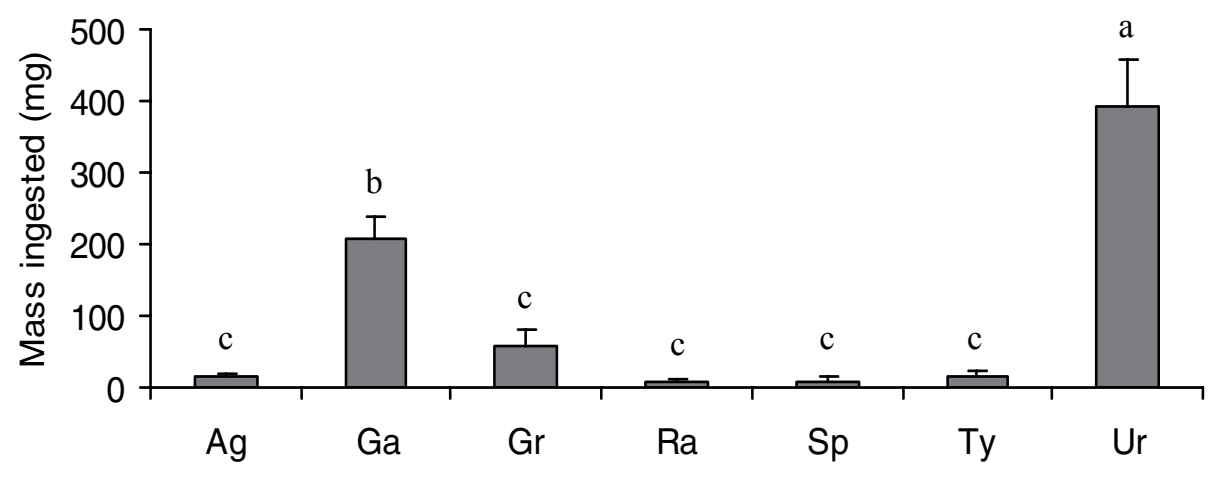

summer

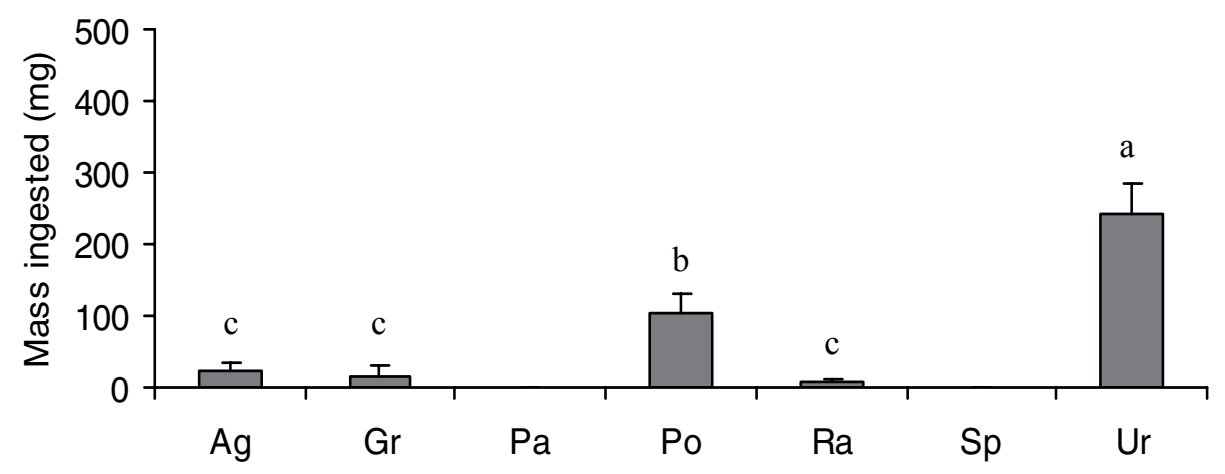

autumn

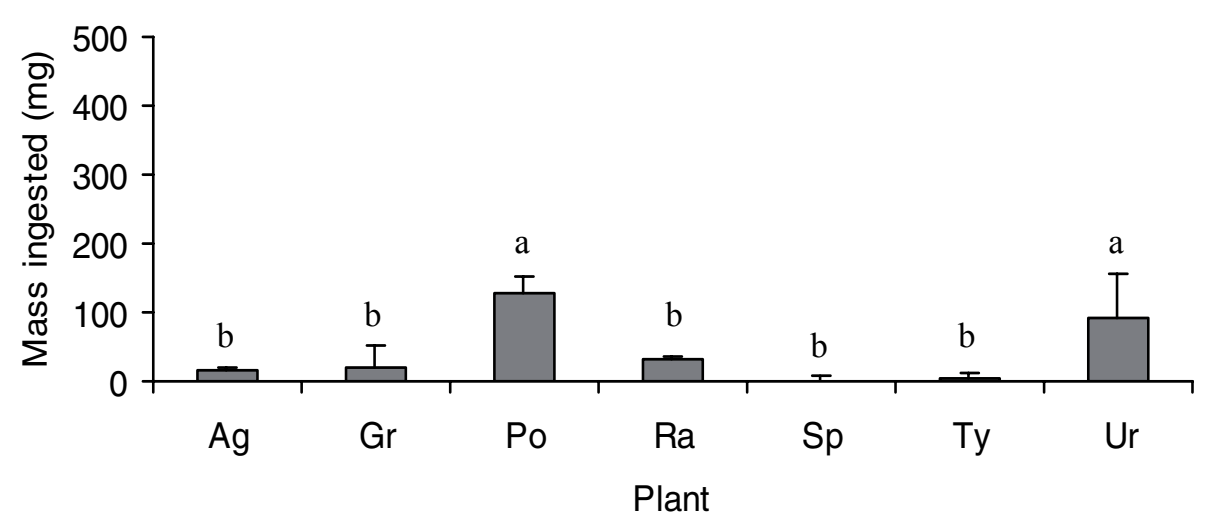

Figure 1

Mean (+SE) mass (in $\mathrm{mg}$ ) of the offered plants ingested by crayfish during multiple choice tests conducted in spring, summer, and autumn. See Table I for abbreviations. Letters over bars denote the hierarchy after multiple comparisons tests.

\section{Figure 1}

Masse moyenne (en $\mathrm{mg} \pm \mathrm{SE}$ ) de la plante proposée ingérée par les écrevisses pendant les tests à choix multiples mendés au printemps, en été, et à l'automne. Voir le tableau I pour les abréviations. Les lettres au dessus des barres indiquent la hiérarchie après les tests de comparaison multiples. 
The food material that was not consumed after $48 \mathrm{~h}$ (for plants) or $24 \mathrm{~h}$ (for animals) was dried in an oven at $80^{\circ} \mathrm{C}$ and then weighed to the nearest $0.001 \mathrm{~g}$. The mass of plant tissues fragmented by crayfish but not consumed was also weighed to evaluate mass destruction. The relationship between wet and dry weight was calculated for each food category and crayfish consumption was measured by subtracting both the non-consumed and the destroyed mass from the supplied food quantity. The percentages of organic $\mathrm{C}$ and $\mathrm{N}$ contents were measured for each food category using a gas-chromatography technique (Carlo Erba NA 1500 Analyser). We also controlled for changes on plant mass due to natural leaching by keeping for two days the same mass of each food category in individual containers in the absence of crayfish.

\section{Assimilation efficiency}

Percentages of both the mass (in dry weight) and the organic $\mathrm{C}$ and $\mathrm{N}$ content assimilated by crayfish when they were free to feed on the plants and animals used in the choice experiments were assessed in an experiment conducted in June 1999. Fifty-one adult crayfish (31 males and 20 females, with a cephalothorax length ranging 41-58.5 mm) were isolated in individual aquaria $(45 \times 15 \mathrm{~cm})$ and starved for 10 days. Pre-weighed mass of approximately the same volume of each food category (with the exceptions of $\mathrm{Ga}$ and $\mathrm{Pa}$ ) used in the preference experiments were placed in the aquaria and crayfish were allowed to feed ad libitum on it for two days. To prevent coprophagy, we fixed a polyethylene net of $4 \times 4 \mathrm{~mm}$ mesh at $2 \mathrm{~cm}$ from the bottom. Fecal pellets were collected several times a day, during the experiment and five days after. Uneaten portions of the offered food and fecal pellets were treated as in the preference experiments to obtain the dry weight of food consumed. The assimilation efficiency (AE) of the dry mass of each food category was calculated using the following equation (WHITLEDGE and RABENI, 1997):

$$
\mathrm{AE}(\%)=100 \times \text { (ingested }- \text { defecated) } / \text { ingested }
$$

The assimilation efficiency of the organic $\mathrm{C}$ and $\mathrm{N}$ contents of each food category was also calculated using the above equation, knowing the mass assimilated, the mean percentage of organic $\mathrm{C}$ and $\mathrm{N}$ contents of each food category, and the organic $\mathrm{C}$ and $\mathrm{N}$ content of fecal pellets assessed using a gas-chromatography technique as above. The estimate of $\mathrm{N}$ in fecal pellets appeared unbiased, because the ammonia released into the water during the seven days of the experiment from crayfish excretion, leaching, and food decomposition was low as shown by applying the Nessler's method (APHA et al. 1976; $0.003 \mathrm{mg} \mathrm{L}^{-1}$ with Fi; $0.002 \mathrm{mg} \mathrm{L}^{-1}$ with plants; and $0.003 \mathrm{mg} \mathrm{L}^{-1}$ with either Ea or $\mathrm{Ta}$ ).

\section{Statistical analyses}

When the scores appeared to be drawn from a normally distributed population, we applied parametric statistical techniques following ZAR (1984). Specifically, Student's t-tests (statistic: t) and one-way ANOVAs (after arcsine square root transformation for percentage values, statistic: F), followed by post hoc Tukey tests, were used to compare the organic content and AE of the offered food. The other data were analyzed using nonparametric tests. Wilks tests after Williams'corrections (statistic: G) were used for frequency data and Wilcoxon signed ranks tests (statistic: $z$ for large samples) and Friedman tests (statistic: $F_{r}$ ), followed by multiple comparisons tests, were used for the data obtained from multiple choice preference tests. Parametric and non-parametric measures of correlation were done applying Pearson (statistic: r) and Spearman's rank order correlation tests (statistic: $r_{s}$ ), respectively.

The level of significance at which the null hypothesis was rejected is $\alpha=0.05$. 


\section{RESULTS}

\section{Choice experiments}

The offered food categories were subject to slight changes in their mass due to natural leaching.

Crayfish showed a significant preference for some plants in the three seasons (spring: $F_{r}=82.721$, $d f=6, P<0.0001$; summer: $F_{r}=102.763$, $d f=6, P<0.0001$; autumn: $\mathrm{F}_{\mathrm{r}}=64.380, \mathrm{df}=6, P<0.0001$ ), consuming a larger biomass of $\mathrm{Ur}$ in all the sessions, together with $\mathrm{Ga}$ in spring and $\mathrm{Po}$ in autumn and summer (Figure 1). Conversely, no preference was shown for any animal $\left(F_{r}=0.3, d f=2, n s\right)$ (Figure 2). When offered the preferred plant (Ur) and $\mathrm{Ea}$, the former was significantly preferred $(\mathrm{z}=-2.655, \mathrm{P}<0.01)$ (Figure 3).

No correlation was found between the ingested mass of each plant and its relative abundance in the habitat (spring: $r_{s}=-0.214$; summer: $r_{s}=-0.616$; autumn: $r_{s}=-0.286$; $n=7$, n.s.). Neither was there a relationship between the mass of the plants ingested in the present laboratory experiment and the volume of each plant found in the guts of wild crayfish as assessed in a companion study (GHERARDI and BARBARESI, 2008) (Gr vs. Ty vs. Other monocots vs. dicots: $r_{s}=-0.344, n=12, t=-1.16, d f=10$, n.s.).

Finally, the mass of plants fragmented but not consumed (mass destruction) was positively correlated with the ingested mass in each season (spring: $r=0.795, d f=17$, $P<0.01$; summer: $r=0.733$, $d f=19, P<0.01$; autumn: $r=0.813$, $d f=18, P<0.01$ ).

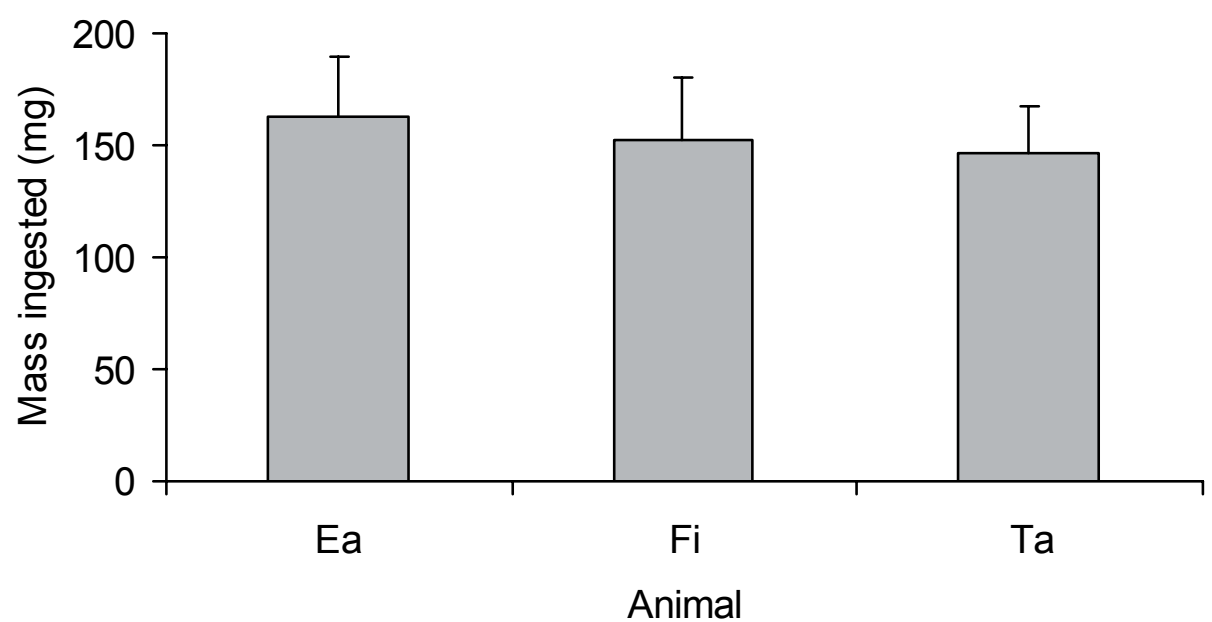

Figure 2

Mean (+SE) mass (in $\mathrm{mg}$ ) of the offered animals ingested by crayfish during a multiple choice test conducted in autumn. Ea=Lumbricus terrestris, Fi=Oncorhynchus mykiss fry, and Ta=Bufo bufo tadpoles.

Figure 2

Masse moyenne (en $\mathrm{mg} \pm \mathrm{SE}$ ) d'animal proposé ingéré par les écrevisses pendant les tests à choix multiples menés en automne. Ea=Lumbricus terrestris, $\mathrm{Fi}=$ Oncorhynchus mykiss alevin, et $\mathrm{Ta}=B$ ufo bufo têtard. 


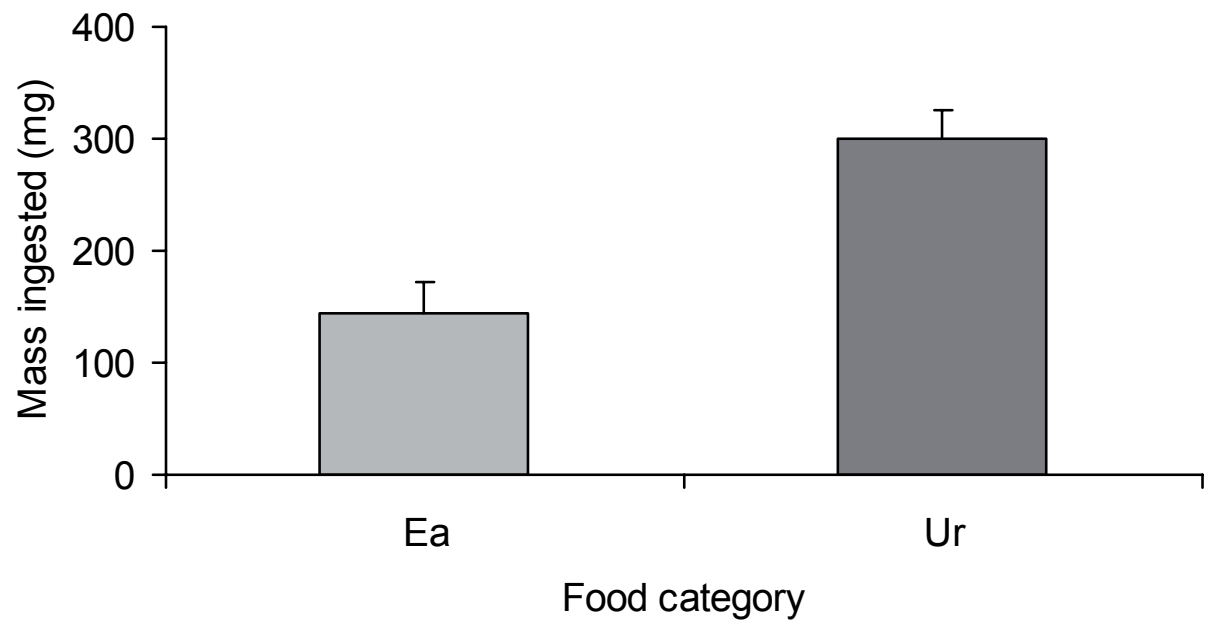

\section{Figure 3}

Mean mass (in $\mathrm{mg}$ ) ingested by crayfish during a binary choice test conducted in autumn when simultaneously offered Lumbricus terrestris (Ea) and Urtica sp. (Ur).

\section{Figure 3}

Masse moyenne (en $\mathrm{mg}$ ) ingérée par les écrevisses pendant le test de choix binaire réalisé en automne et pendant lequel Lumbricus terrestris (Ea) et Urtica sp. (Ur) ont été proposés simultanément.

\section{Organic content and assimilation efficiency}

Data on the organic content and AE of each food category and statistical outputs are shown in Tables II and III, respectively.

The plants and animals used in choice tests showed significant differences in both their organic content and the $A E$ of both $C$ and $N$ contents. Conversely, the AE of their dry mass differed among animals but not among plants. A direct comparison between Ea and Ur showed that the former contained higher percentages of organic $\mathrm{C}$ and $\mathrm{N}$ and had a higher AE of its dry mass but a similar AE of organic content.

The ingested mass per plant was independent of its organic content ( $C: r_{s}=-0.723$, $n=7$, n.s.; $N$ : $r_{s}=-0.071, n=7$, n.s.), its $A E\left(C: r_{s}=-0.464, n=7\right.$, n.s.; $N: r_{s}=-0.357, n=7$, n.s.), and the AE of its dry mass $\left(r_{s}=0.071, n=7, n . s.\right)$.

\section{DISCUSSION}

As a confirmation of previous studies (ILHÉU and BERNARDO, 1995; BOLSER et al., 1998; CRONIN et al., 2002; CIRUJANO et al., 2004; GHERARDI and BARBARESI, 2008), our results show that $P$. clarkii is a selective feeder of fresh plants (Urtica in the three seasons examined, green algae in spring, and Polygonum in summer and autumn). A similar selectivity was observed, for instance, in a wetland of Spain where $P$. clarkii significantly preferred Chara hispida over Ceratophyllum submersum, despite their similar abundance in the study area (CIRUJANO et al., 2004). 

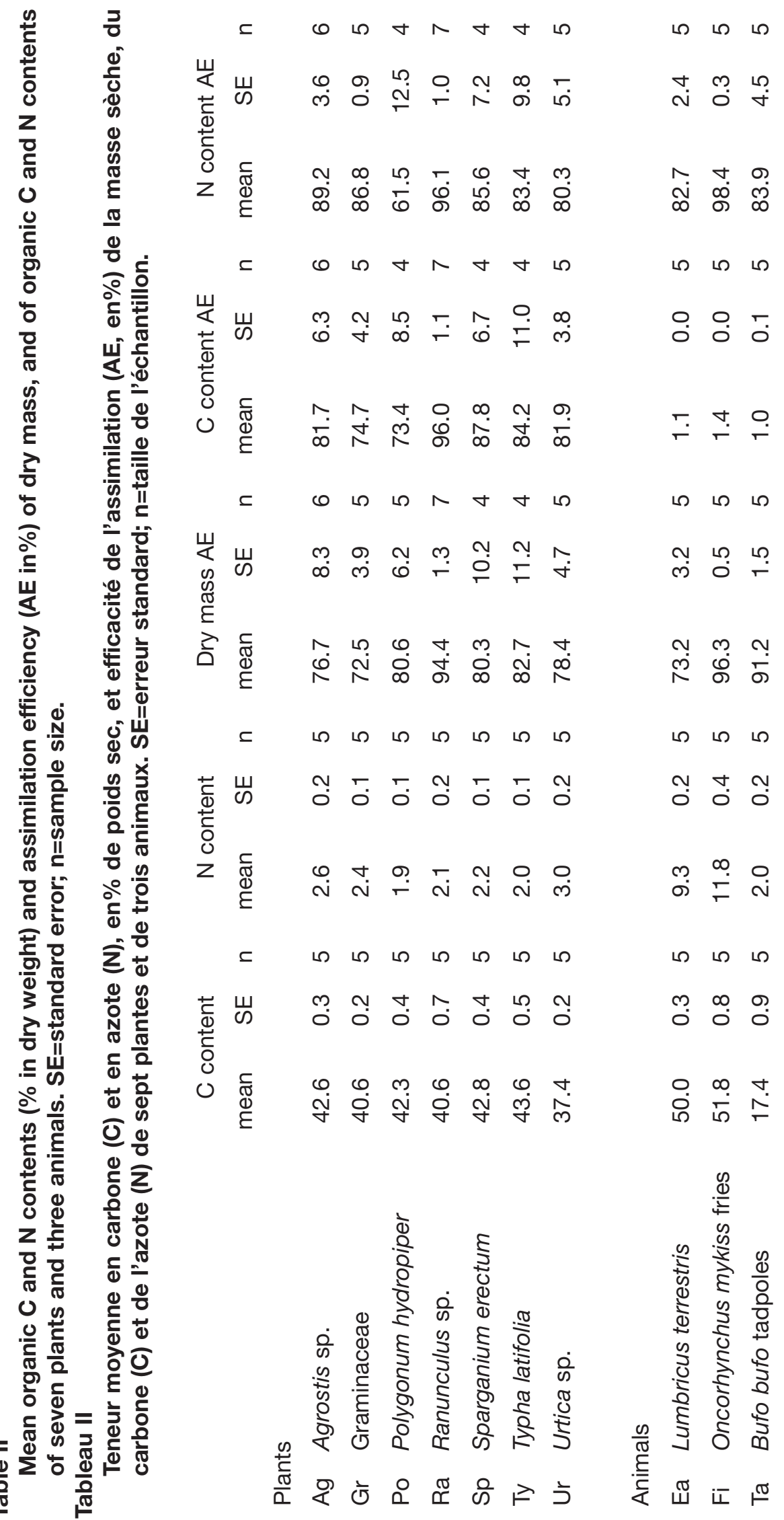


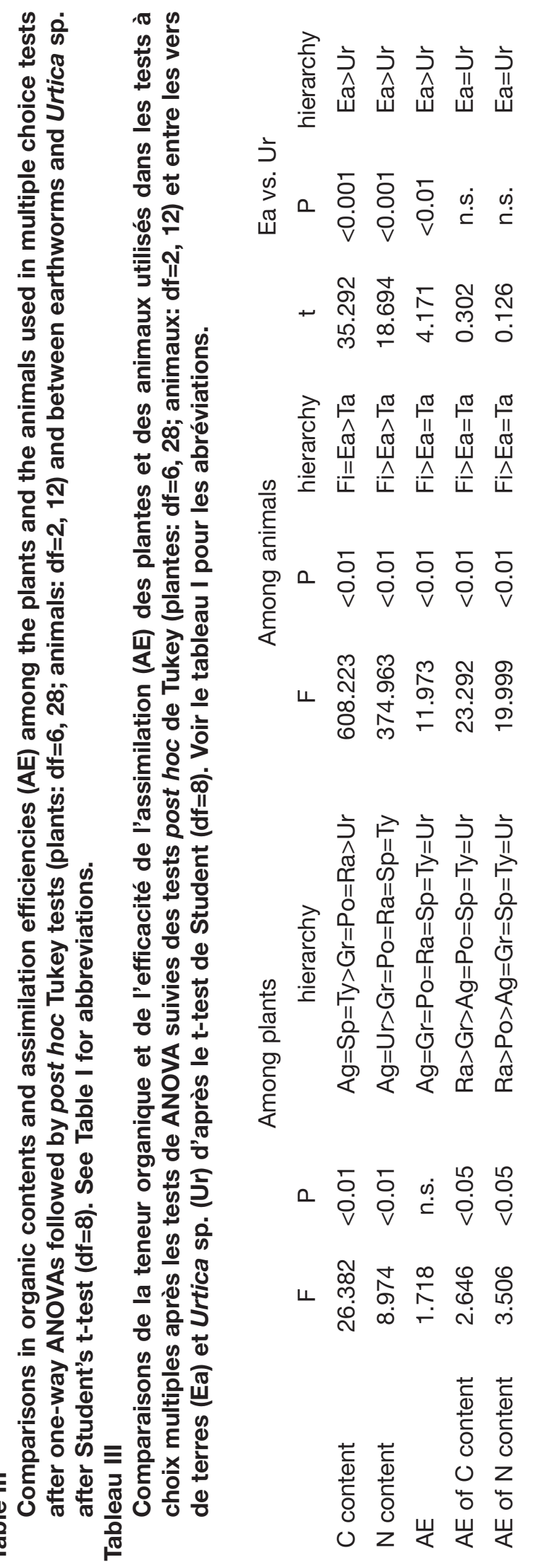


Indeed, food selectivity is a prerogative of most Astacoidea, as reported in natural conditions (LODGE and LORMAN, 1987), laboratory experiments (CHAMBERS et al., 1991; SAFFRAN and BARTON, 1993; NYSTRÖM and STRAND, 1996; GHERARDI et al., 2004), and controlled mesocosm studies (CHAMBERS et al., 1990; HANSON et al., 1990). However, a number of anomalies were revealed in the present study. First, we were unable to find a clear relationship between crayfish feeding decisions and either the availability of plants in the habitat or their occurrence in the gut contents of wild individuals. Neither did the ingested biomass of plants depend on their organic content or assimilation efficiency. This contrasts with previous studies; for instance, the preference for moss observed in A. pallipes by GHERARDI et al. (2004) was correlated with its relatively higher nutritional quality and assimilation efficiency.

An explanation of our results might be that feeding preferences often depend on factors other than nutritional value and digestibility (CHAMBERS et al., 1991) and that the influence of these factors may vary with species and habitats. Several studies underlined the importance of plant morphology and structure (BRYANT and KUROPAT, 1980). BOLSER et al. (1998), for instance, showed that, while $P$. clarkii consumes much more fresh tissue from Ceratophyllum demersum than from Typha angustifolia, once their structural and morphological differences were removed (i.e. plants were freezedried, finely ground, and embedded in an agar matrix), crayfish preference switched to Typha. A given morphology, in fact, may make a plant easier to handle and to consume, thus playing a major role in feeding decisions. Similarly, LODGE and LORMAN (1987) observed that Orconectes rusticus favored single-stemmed species over rosulate or highly branched forms, and BOLSER et al. (1998) showed that $P$. clarkii feeds upon plants with a filamentous structure; Orconectes virilis was found to choose the macroalga Chara and the duckweed species Lemna, possibly because the number of stalks or individual plants per unit weight is higher with respect to other plants (CHAMBERS et al., 1991). Finally, to be preferentially consumed, a macrophyte must lack chemical deterrents, such as alkaloids (CHAMBERS et al., 1991) and phenolics (LODGE, 1991; BOLSER et al., 1998). Habenaria repens, for instance, was avoided by $P$. clarkii in both fresh-plant and agar-based assays because of the deterrent chemical compound (the habenariol) it contained (BOLSER et al., 1998).

Surprisingly, P. clarkii did not show preference for any animal prey. Procambarus clarkii usually acts as a scavenger, feeding on dead, dying or immobilized fish and amphibians (RENAI and GHERARDI, 2004; an exception in ILHÉU et al., 2007), which justifies the use of dead prey in our experiment. In its turn, the lack of prey's mobility might have favored the selection of corpses richer in organic content and easier to be assimilated, but it did not, suggesting that $P$. clarkii's scavenger activity may be independent of both the nutritional quality and the assimilation efficiency of the prey encountered.

Similarly surprising is the preference exhibited for Urtica sp. over earthworms, notwithstanding the higher nutritional value and assimilation efficiency of the latter and the apparently easier handling of it. This result contrasts with ILHÉU and BERNARDO's (1993) finding that, when mosquitofish and detritus were simultaneously presented to $P$. clarkii, if the former was alive, the crayfish consumed higher quantities of detritus than fish, but, if it was dead, fish consumption increased to very high values. Such a dietary switch can be explained in terms of cost-benefit analysis, in the context of the theory of feeding strategy (SCHOENER, 1971): when the capture of prey has a high efficiency, detritivory might shift to a carnivorous habit. This theory seems to fail in our case, likely because the preference we recorded for Urtica might depend on factors other than its nutritional value and assimilation efficiency, such as some peculiar substances contained in the plant that might make it particularly attractive to crayfish, but also the crayfish's larger familiarity with it. 
Indeed, CRONIN et al.'s (2002) detailed analysis of $P$. clarkii's responses to the morphology, toughness, surface features, and chemistry of 14 species of macrophytes showed that crayfish selectivity depends on a long list of plant properties (phenolics, protein, nitrogen, fiber, lignin, cellulose, ash, and carbon), none of which is a good predictor of their palatability. A similar list was compiled by CIRUJANO et al. (2004): the macrophyte preferred by P. clarkii (C. hispida) had a lower content of protein, nitrogen, phosphorous, sodium, potassium, magnesium, and phenolic compounds than the unpreferred $C$. submersum, but a higher calcium content. To make the picture more complex, other factors may also be important in determining feeding decisions (GHERARDI, 2007). These include cover or protection from predators afforded by the plant (e.g. DAMMAN, 1987), the consumer's state or hunger (e.g. CRONIN and HAY, 1996; HUNER and MEYERS, 1979), the consumer's prior feeding experiences (e.g. DORN et al., 2001), and the abundance of alternative foods (CHAMBERS et al., 1990).

To conclude, we expect that future studies will be able to analyze all the above factors together in order to unravel the rules that govern crayfish feeding decisions. Such knowledge seems to be particularly urgent in the case of invasive crayfish species. Their intense grazing on aquatic macrophytes (e.g. LODGE et al., 1994; NYSTRÖM et al., 1996; GHERARDI and ACQUISTAPACE, 2007), coupled with their non-consumptive plant clipping and uprooting (LODGE et al., 1994; NYSTRÖM and STRAND, 1996; GHERARDI and ACQUISTAPACE, 2007; GHERARDI and BARBARESI, 2008; this study), is leading worldwide to a significant decline in macrophyte abundance. And their direct and indirect impact on animal communities is causing local (and global) extinctions of indigenous species in all the systems invaded (reviewed in GHERARDI, 2007). When the goal is to face the threats that invasive crayfish pose, an understanding of their feeding preferences can highly contribute to planning science-based actions for their containment and mitigation -before it will be too late.

\section{ACKNOWLEDGEMENTS}

Our heartfelt thanks are directed to Gabriele Salvi for his help during data collection.

\section{REFERENCES}

APHA, AWWA, WPCF, 1976. Standard methods for the examination of water and wastewater. $-14^{\text {th }}$ edition. American Public Health Association, Washington, DC.

BARBARESI S., TRICARICO E., SANTINI G., GHERARDI F., 2004. Ranging behaviour of the invasive crayfish, Procambarus clarkii. J. Nat. Hist., 38, 2821-2832.

BOLSER R.C., HAY M.E., LINDQUIST N., FENICAL W., WILSON D., 1998. Chemical defenses of freshwater macrophytes against crayfish herbivory. J. Chem. Ecol., 24, 1639-1657.

BRYANT J.P., KUROPAT P.J., 1980. Selection of winter forage by subarctic browsing vertebrates: the role of plant chemistry. Ann. Rev. Ecol. Syst., 11, 261-285.

CHAMBERS P.A., HANSON J.M., BURKE J.M., PREPAS E.E., 1990. The impact of the crayfish Orconectes virilis on aquatic macrophytes. Freshwat. Biol., 24, 81-91.

CHAMBERS P.A., HANSON J.M., PREPAS E.E., 1991. The effect of aquatic plant chemistry and morphology on feeding selectivity by the crayfish, Orconectes virilis. Freshwat. Biol., 25, 339-348.

CIRUJANO S., CAMARGO J.A., GÓMEZ-CORDOVÉS C., 2004. Feeding preferences of the red swamp crayfish Procambarus clarkii (Girard) on living macrophytes in a Spanish wetland. J. Freshwat. Ecol., 19, 219-226.

CORREIA A.M., 2003. Food choice by the introduced crayfish Procambarus clarkii. Ann. Zool. Fennici, 40, 517-528. 
CRONIN G., HAY M.E., 1996. Seaweed-herbivore interactions depend on recent history of both the plant and animal. Ecology, 77, 1531-1543.

CRONIN G., LODGE D.M., HAY M.E., MILLER M., HILL A.M., HORVATH T., BOLSER R.C., LINDQUIST N., WAHL M., 2002. Crayfish feeding preferences for fresh water macrophytes: The influence of plant structure and chemistry. J. Crustacean Biol., $22,708-718$.

CRUZ M.J., REBELO R., 2005. Vulnerability of Southwest lberian amphibians to an introduced crayfish, Procambarus clarkii. Amphibia-Reptilia, 26, 293-303.

DAMMAN H., 1987. Leaf quality and enemy avoidance by the larvae of a pyralid moth. Ecology, 68, 88-97.

DORN N.J., CRONIN G., LODGE D.M., 2001. Feeding preferences and performance of an aquatic lepidopteran on macrophytes: plant hosts as food and habitat. Oecologia, 128, 406-415.

FEMINELLA J.W., RESH V.H., 1989. Submersed macrophytes and grazing crayfish: an experimental study of herbivory in a Californian freshwater marsh. Hol. Ecol., 12, $1-8$.

GAMRADT S.C., KATS L.B., 1996. Effect of introduced crayfish and mosquito fish on California newts (Taricha torosa). Conserv. Biol., 10, 1155-1162.

GHERARDI F., 2006. Crayfish invading Europe: the case study of Procambarus clarkii. Mar. Freshwat. Behav. Physiol., 39, 175-191.

GHERARDI F., 2007. Understanding the impact of invasive crayfish. In: F. GHERARDI (ed.). Biological invaders in inland waters: profiles, distribution, and threats. Springer, Dordrecht, The Netherlands, pp. 507-542.

GHERARDI F., ACQUISTAPACE P., 2007. Invasive crayfish in Europe: the impact of Procambarus clarkii on the littoral community of a Mediterranean lake. Freshwat. Biol., 52, 1249-1259.

GHERARDI F., ACQUISTAPACE P., SANTINI G., 2004. Food selection in omnivores: a case study of the crayfish Austropotamobius pallipes. Archiv Hydrobiol., 159, 357-376.

GHERARDI F., BARBARESI S., 2007. Feeding opportunism of the red swamp crayfish, Procambarus clarkii, an invasive species. Freshwat. Crayfish, 16, in press.

GHERARDI F., BARBARESI S., SALVI G., 2000. Spatial and temporal patterns in the movement of Procambarus clarkii, an invasive crayfish. Aq. Sc., 62,179-193.

GHERARDI F., RENAI B., CORTI C., 2001. Crayfish predation on tadpoles: a comparison between a native (Austropotamobius pallipes) and an alien species (Procambarus clarkii). Bull. Franç. Pêche Piscicult., 361, 659-668.

GUAN R.-Z., WILES P.R., 1997. Ecological impact of introduced crayfish on benthic fishes in a British lowland river. Conserv. Biol., 11, 641-647.

HANSON J.M., CHAMBERS P.A., PREPAS E.E., 1990. Selective foraging by the crayfish Orconectes virilis and its impact on macroinvertebrates. Freshwat. Biol., 24, 69-80.

HOBBS H.H. III, JASS J.P., HUNER J.V., 1989. A review of global crayfish introductions with particular emphasis on two North American species (Decapoda, Cambaridae). Crustaceana, 56, 299-316.

HUNER J.V., MEYERS S.P., 1979. Dietary protein requirements of the red crawfish Procambarus clarkii (Girard) (Decapoda, Cambaridae). Proceedings of the World Mariculture Society, 10, 751-760. 
ILHÉU M., BERNARDO J.M., 1993. Experimental evaluation of food preference of red swamp crayfish, Procambarus clarkii: vegetal versus animal. Freshwat. Crayfish, 9, 359-364.

ILHÉU M., BERNARDO J.M., 1995. Trophic ecology of red swamp crayfish Procambarus clarkii (Girard) -preference and digestability of plant foods. Freshwat. Crayfish, 10, 132-139.

ILHÉU M., BERNARDO J.M., FERNANDES S., 2007. Predation of invasive crayfish on aquatic vertebrates: the effect of Procambarus clarkii on fish assemblages in Mediterranean temporary streams. In: F. GHERARDI (ed.). Biological invaders in inland waters: profiles, distribution, and threats. Springer, Dordrecht, The Netherlands, pp. 543-558.

LODGE D.M., 1991. Herbivory on freshwater macrophytes. Aq. Botany, 41, 195-224.

LODGE D.M., LORMAN J.G., 1987. Reductions in submersed macrophyte biomass and species richness by the crayfish Orconectes rusticus. Can. J. Fish. Aq. Sci., 44, 591-597.

LODGE D.M., KERSHNER M.W., ALOI J.E., COVICH A.P., 1994. Effects of an omnivorous crayfish (Orconectes rusticus) on a freshwater littoral food web. Ecology, 75, 12651281.

MOMOT W.T., 1995. Redefining the role of crayfish in aquatic ecosystems. Rev. Fish. Sci., 3, 33-63.

NYSTRÖM P., 1999. Ecological impact of introduced and native crayfish on freshwater communities: European perspectives. In F. GHERARDI and D.M. HOLDICH (eds.). Crayfish in Europe as alien species: How to make the best of a bad situation? A. A. Balkema, Rotterdam, The Netherlands, pp. 63-84.

NYSTRÖM P., 2002. Ecology. In: D.M. HOLDICH (ed.). Biology of freshwater crayfish. Blackwell, Oxford, U.K, pp. 192-235.

NYSTRÖM P., BRÖNMARK C., GRANÉLI W., 1996. Patterns in benthic food webs: a role for omnivorous crayfish? Freshwat. Biol., 36, 631-646.

NYSTRÖM P., STRAND J.A., 1996. Grazing by a native and an exotic crayfish on aquatic macrophytes. Freshwat. Biol., 36, 673-682.

NYSTRÖM P., SVENSSON O., LARDNER B., BRÖNMARK C., GRANÉLI W., 2001. The influence of multiple introduced predators on a littoral pond community. Ecology, 82, 1023-1039.

RENAI B., GHERARDI F., 2004. Predatory efficiency of crayfish: comparison between indigenous and non-indigenous species. Biol. Inv., 6, 89-99.

SAFFRAN K.A., BARTON D.R., 1993. Trophic ecology of Orconectes propinquus (Girard) in Georgian Bay (Ontario, Canada). Freshwat. Crayfish, 9, 350-354.

SCHOENER T.W., 1971. Theory of feeding strategies. Ann. Rev. Ecol. Syst., 11, 369-404.

WARNER G.F., GREEN E.I., 1995. Choice and consumption of aquatic weeds by signal crayfish (Pacifastacus leniusculus). Freshwat. Crayfish, 8, 360-363.

WHITLEDGE G.W., RABENI C.F., 1997. Energy sources and ecological role of crayfishes in an Ozark stream: insights from stable isotopes and gut analysis. Can. J. Fish. Aq. Sci., 54, 2555-2563.

ZAR J.H., 1984. Biostatistical Analysis. Prentice-Hall Inc., Englewood Cliffs, New Jersey, U.S.A. 